\title{
In vitro Antagonistic Potential, Plant Growth-promoting Activity and Indole-3-acetic Acid Producing Trait of Bacterial Isolates from Button Mushroom (Agaricus bisporus) Spent Substrate
}

Shima Nasser Hamed Al-Mamari ${ }^{1}$, Abdullah Mohammed Al-Sadi ${ }^{1}$, S. P. Sathish Babu ${ }^{2}$, Issa Hashil Al-Mahmooli ${ }^{1}$, Rethinasamy Velazhahan ${ }^{1, *}$

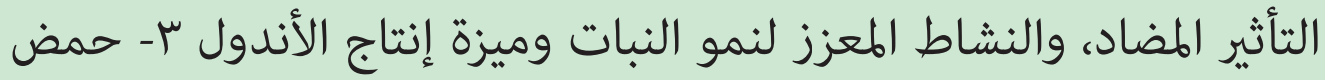

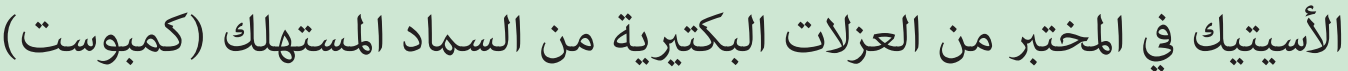

$$
\begin{aligned}
& \text { بعد إنتاج فطر المشروم الدائري (Agaricus bisporus) }
\end{aligned}
$$

شيماء بنت ناصربن حمد المعمرية'، عبدالله بن محمد السعلي'، ساثيش بابو'، عيسى بن هاشل المهمولي' و

$$
\text { راثيناسمي فيلازهاهن' }
$$

ABSTRACT. Spent mushroom substrate (SMS) is widely used as a fertilizer and to control plant diseases. The microorganisms surviving in SMS play a crucial role in plant growth promotion and biocontrol activity. In this study, an effort was made to isolate and characterize the bacterial species present in the SMS of Agaricus bisporus and to study their antagonistic potential, plant growth-promoting ability and indole-3-acetic acid (IAA) producing trait. Six different bacterial isolates exhibiting morphological variabilities were obtained from the SMS by serial dilution technique. On the basis of 16S rRNA gene sequences, these isolates were identified as Staphylococcus epidermidis (Sh1 and Sh3), S. aureus (Sh2), Bacillus albus (Sh4), Delftia lacustris (Sh6) and Comamonas aquatica (Sh7). These bacterial strains were assayed for their antagonism against Pythium aphanidermatum, a phytopathogenic oomycete. The results of in vitro dual culture assay revealed that all the 6 bacterial isolates showed low levels of suppression of $P$. aphanidermatum and recorded less than $5 \mathrm{~mm}$ inhibition zone. Among the bacterial isolates, S. epidermidis Sh3 recorded the maximum inhibition zone of $4.2 \pm 0.5 \mathrm{~mm}$. Plant growth promotion test using roll paper towel method revealed that $\mathrm{C}$. aquatica Sh7, B. albus Sh4, D. lacustris Sh6 and S. epidermidis Sh3 caused a significant increase in seedling vigour of cucumber compared to control. The seeds treated with the bacterial isolate C. aquatica Sh7 showed the maximum seedling vigor $(2018 \pm 255)$. Assessment of in vitro production of IAA by the bacterial isolates revealed that the bacterial isolates highly varied (ranging from 0.28 to $9.25 \mathrm{mg} \mathrm{L}^{-1}$ ) in their potential for production of IAA. The maximum amount of IAA was produced by $\mathrm{C}$. aquatica Sh7 $\left(9.25 \pm 0.02 \mathrm{mg} \mathrm{L}^{-1}\right)$. Further studies are required to assess the possibility of using the IAA-producing bacterial isolates identified in this study or their metabolites to promote plant growth or to enhance growth and yield of mushrooms.

KEYWORDS: Button mushroom; spent compost; IAA production; Agaricus bisporus; antagonistic activity; plant growth promotion.

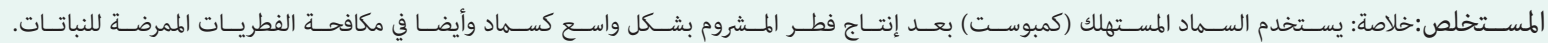

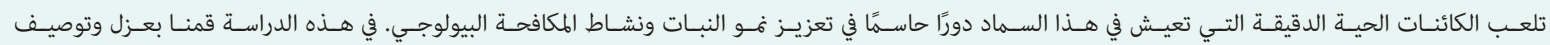

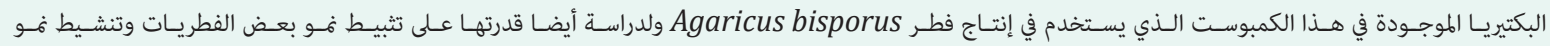

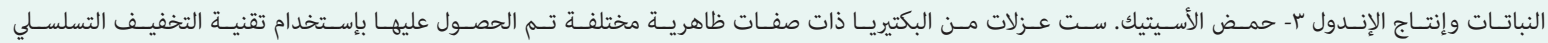

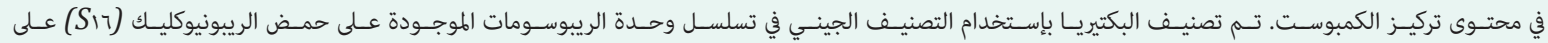

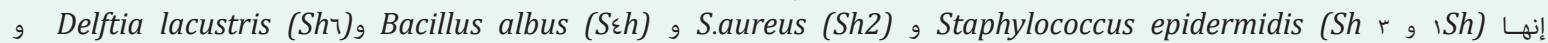

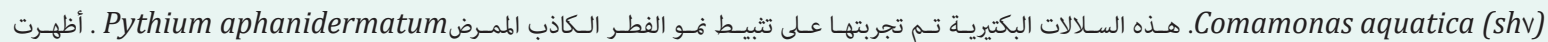

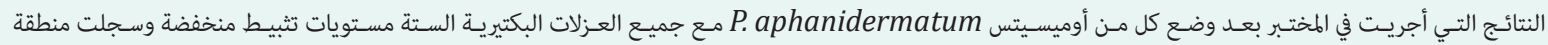

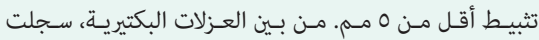

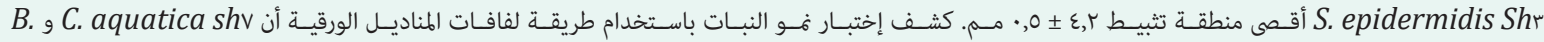

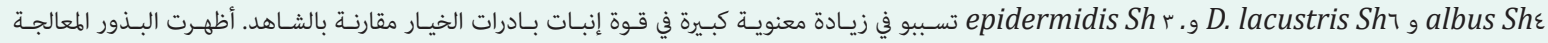

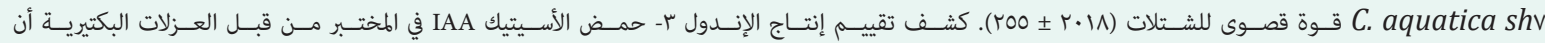

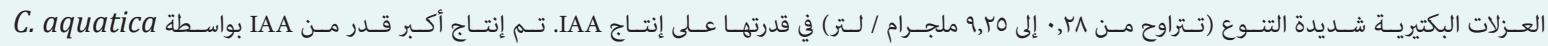

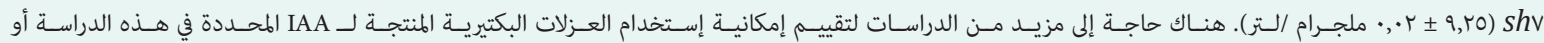

$$
\text { نواتجهـم لتعزيـز فــو النبـات أو لتعزيـز فهو وإنتـاج الفطر. }
$$




\section{الكلمات المفتاحية: الفطر الدائري، السماد المستهلك، إنتاج IAA، Agaricus bisporus، نشاط تثبيط، تعزيز فو النبات}

\section{Introduction}

$\mathrm{M}$

ushroom farming has gained recognition in the recent years and has emerged as a promising agro-based business. Malaysia, China, India and Ireland are the world's leading edible mushrooms producers (Hanafi et al., 2018). Several edible mushrooms including button mushroom (Agaricus bisporus), shiitake mushroom (Lentinula edodes), paddy straw mushroom (Volvariella volvacea), oyster mushroom (Pleurotus spp.) and enoki mushroom (Flammulina ostreatus) are being cultivated commercially worldwide (Feeney et al., 2014). Agaricus bisporus is cultivated commercially in Oman. Mixtures of agricultural/poultry/industrial wastes are commonly used as substrates for mushroom cultivation. The mushroom industry discharges huge quantities of spent mushroom substrate (SMS) after harvest. The SMS usually contains mycelia and remnants of fruiting bodies of mushrooms, and the substrate used for cultivation of mushrooms (Kang et al., 2017). A wide variety of biologically active compounds such as extracellular enzymes, antimicrobial compounds and secondary metabolites that are mainly produced by mushrooms are present in the SMS (Kwak et al., 2015). The potential of SMS in large-scale enzymes production, plant diseases control, bioremediation, fertilizer, vermicomposting and for feeding animals has been documented (Inagaki and Yamaguchi, 2009; Ahlawat et al., 2011; Parada et al., 2011; Parada et al., 2012; Kwak et al., 2015; Roy et al., 2015). Several reports indicated the effectiveness of SMS in plant disease management (Yohalem et al., 1996; Uzun, 2004; Goonani et al., 2011; Riahi et al., 2012). Riahi et al. (2012) demonstrated that the extract of SMS inhibited the growth of Lecanicillium fungicola, the causal fungus of dry bubble disease of A. bisporus. Kang et al. (2017) reported that aqueous extract prepared from SMS of Lentinula edodes suppressed the growth of Phytophthora capsici, reduced the Phytophthora blight and enhanced the growth of pepper. The antagonistic microorganisms present in the SMS were attributed to the disease suppression (Riahi et al., 2012). The objectives of the present study were to isolate and characterize the bacterial species present in the spent mushroom substrate of A. bisporus in Oman and to study their in vitro antagonistic potential, plant growth-promoting trait and IAA producing ability.

Rethinasamy Velazhahan ${ }^{1, *}(\checkmark)$ velazhahan@squ.edu.om, ${ }^{1}$ Department of Plant Sciences, College of Agricultural and Marine Sciences, Sultan Qaboos University, P.O. Box 34, Al-Khoud, Muscat 123, Sultanate of Oman. ${ }^{2}$ Central Analytical and Applied Research Unit, College of Science, Sultan Qaboos University, Al-Khoud, Muscat 123, Sultanate of Oman.

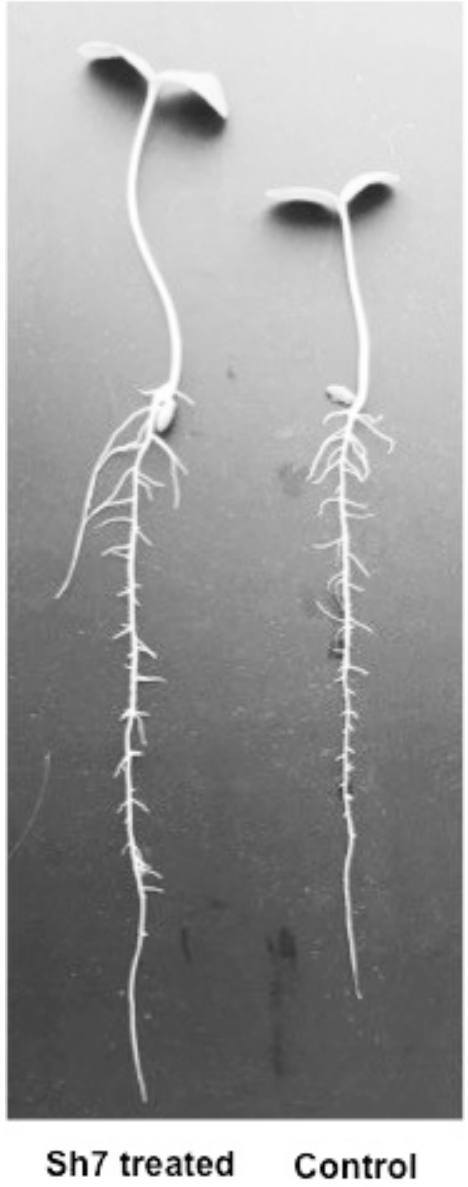

Figure 1. Enhancement of cucumber growth by seed bacterization with Comamonas aquatica Sh7 isolated from spent mushroom substrate of Agaricus bisporus

\section{Materials and Methods}

\section{SMS Collection and Bacterial Isolation}

Spent mushroom substrate of A. bisporus was obtained from the Department of Plant Sciences, CAMS, Sultan Qaboos University. Bacteria from the SMS were isolated by employing serial dilution plate technique. Briefly, 1 $\mathrm{g}$ of SMS was suspended in $99 \mathrm{ml}$ of sterile water and kept on a rotary shaker (150 rpm) for $30 \mathrm{~min}$. Later, the suspension was serially diluted at 1:10 ratio with sterile water. An aliquot $(100 \mu \mathrm{l})$ from $10^{-4}$ to $10^{-7}$ dilutions was gently spread over the Nutrient agar (NA) (Oxoid, UK) with a sterile spreader and then the Petri plates were incubated at $30^{\circ} \mathrm{C}$ for $48 \mathrm{~h}$. The bacterial colonies with varying morphological features were selected and transferred to fresh NA plates. 


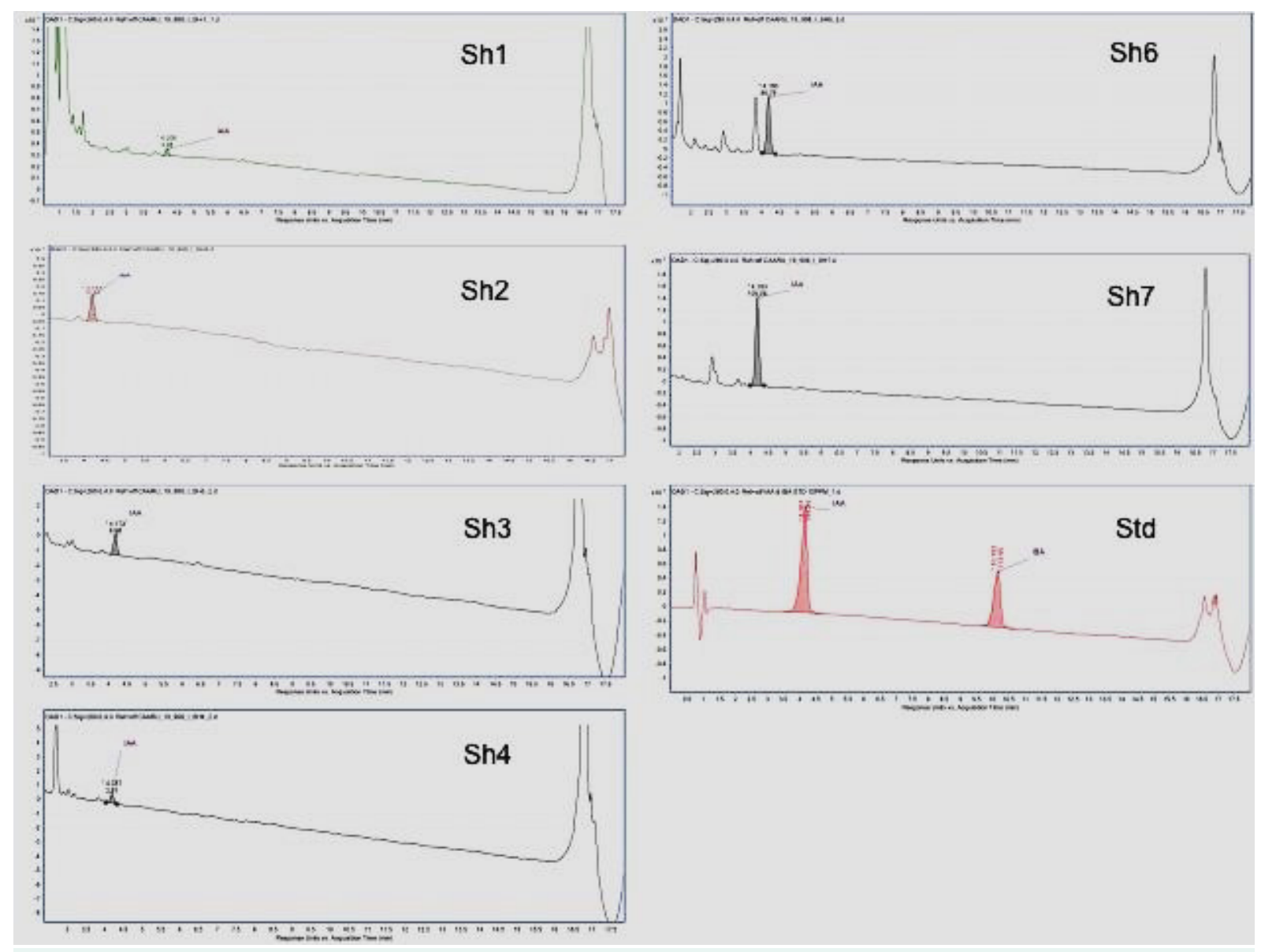

Figure 2. HPLC chromatograms showing IAA produced by bacterial strains from spent mushroom substrate of Agaricus bisporus

\section{Test pathogen}

A virulent isolate of Pythium aphanidermatum, the cucumber damping-off pathogen (Al-Shibli et al., 2019), was used in this study. The oomycete pathogen was multiplied on potato dextrose agar (PDA) (Oxoid, UK) at $25 \pm 2^{\circ} \mathrm{C}$

\section{Bacterial Isolates Screening Against P. aphani- dermatum}

The bacterial isolates were screened for their inhibitory effect on P. aphanidermatum using an in vitro dual culture method as described by Al-Hussini et al. (2019). Briefly, a mycelial plug (7 mm diameter) of P. aphanidermatum was placed aseptically on one end of the Petri plate ( $9 \mathrm{~cm}$ diameter) containing PDA. The bacterial isolate was streaked on the other side of the Petri plate $(\sim 1$ $\mathrm{cm}$ away from the margin). The inoculated plate was incubated at $27{ }^{\circ} \mathrm{C}$ for 3-5 days. After incubation, the inhibition zone was measured. Petri plates inoculated with P. aphanidermatum discs alone were used as control. Four replications were maintained for each bacterial isolate.

\section{Molecular Identification of Bacterial Isolates}

The $16 \mathrm{~S}$ rRNA gene sequence analysis was employed for identification of the bacterial isolates. The bacterial isolates were grown individually on a shaker in nutrient broth (NB) medium $(100 \mathrm{ml})$ at $30^{\circ} \mathrm{C}$ for $48 \mathrm{~h}$. The bacterial cultures were centrifuged at $14000 \mathrm{~g}$ for $15 \mathrm{~min}$ and the bacterial cell pellets were collected. DNA was extracted from the bacterial pellet using a commercial foodproof StarPrep Two DNA extraction kit (BIOTECON Diagnostics, Germany). The universal primers $27 \mathrm{~F}$ (5'-AGAGTTTGATCMTGGCTCAG-3') and 1429R (5'-TACGGYTACCTTACGACTT- ${ }^{\prime}$ ) were used for amplification of bacterial 16S rRNA gene by PCR as described by Al-Hussini et al. (2019). The PCR amplified products were sequenced at Macrogen Inc., Seoul, Korea. A database search of homologous sequences was carried out using National Center for Biotechnology Information (NCBI) BLASTN program (http://www.ncbi. nlm.nih.gov). 
Table 1. Identification of bacterial isolates from spent mushroom substrate of Agaricus bisporus by $16 \mathrm{~S}$ rDNA sequence analysis

\begin{tabular}{|cccc} 
Bacterial isolate & GenBank accession number & Hit in the NCBI database & $\%$ identity \\
Sh1 & MT002750 & Staphylococcus epidermidis (KX348319.1) & 99.87 \\
Sh2 & MT002751 & Staphylococcus aureus (CP045468.1) & 100 \\
Sh3 & MT002756 & Staphylococcus epidermidis (LC499612.1) & 100 \\
Sh4 & MT002776 & Bacillus albus (MN793202.1) & 100 \\
Sh6 & MT002777 & Delftia lacustris (MF457528.1) & 100 \\
Sh7 & MT002779 & Comamonas aquatica (MN216294.1) & 100
\end{tabular}

\section{Plant Growth Promoting Activity of Bacterial Isolates}

Each bacterial isolate was cultured in NB medium (100 $\mathrm{ml})$ in $250 \mathrm{ml}$ conical flask on a shaker $(200 \mathrm{rpm} / \mathrm{min})$ at $30^{\circ} \mathrm{C}$ for $48 \mathrm{~h}$, and then the bacterial suspension was centrifuged at $3000 \mathrm{rpm}$ for $10 \mathrm{~min}$. The bacterial cell pellet was collected and re-suspended in sterile distilled water and the concentration of the bacterial cells was adjusted to $4 \times 10^{8} \mathrm{CFU} \mathrm{\textrm {ml } ^ { - 1 }}$. Cucumber seeds (cv. Jabbar, F1; US Agriseeds, USA) were immersed in the bacterial suspension for $3 \mathrm{~h}$ at room temperature $\left(25 \pm 2{ }^{\circ} \mathrm{C}\right)$, while the control seeds were soaked in sterile distilled water. The roll paper towel method (Shifa et al., 2015) was used to test the effect of bacterial strains on the growth of cucumber. The percentage of cucumber seed germination, seedling shoot length and root length were recorded 12 days after treatment and vigor index was calculated by multiplying the germination percentage of seeds with the total of seedling root length and shoot length. Four replicates of 10 seeds each were used for each treatment.

\section{Analysis of IAA Production}

The bacterial isolates were cultivated in NB medium supplemented with $5 \mathrm{mM}$ Tryptophan in a shaker $(200$ rpm) for $72 \mathrm{~h}$ at $30^{\circ} \mathrm{C}$. The cultures were centrifuged at $14000 \mathrm{~g}$ for $10 \mathrm{~min}$ at $4^{\circ} \mathrm{C}$ and the culture supernatants were collected. The IAA content in the cell-free bacterial culture supernatants was analyzed by High-performance liquid chromatography (HPLC) (Szkop and Bielawski, 2013). Analysis of IAA was performed using a HPLC system (Agilent-1200 Infinity Series), equipped with a high performance autosampler (G4226A), quaternary pump (G4204A), thermostatted column compartment (G1316C) and a diode array detector (DAD) (G4212A). The separation was achieved with Waters Symmetry C8 $(5 \mu \mathrm{m}, 3.0 \times 150 \mathrm{~mm})$ column. The mobile phases consisted of $\mathrm{A}$ ( $2.5 \%$ acetic acid with a $\mathrm{pH} 3.8)$ and $B(80 \%$ acetonitrile). The mobile phase began with eluent $A$ : eluent $B$ at $80: 20$ and changed to 50:50, 0:100, $80: 20$ in 15,16 , and $16.5 \mathrm{~min}$, respectively, and maintained in 80:20 for $1.5 \mathrm{~min}$ with a flow rate $1 \mathrm{ml}$ per min. The detection wavelength was set at $280 \mathrm{~nm}$. Peaks in the sample were identified and quantified by comparing with the standard RT.

\section{Statistical Analysis}

The experimental design used was completely randomized design. The data on mycelial growth inhibition, percent seed germination and seedling growth of cucumber and IAA production by bacterial isolates,were analyzed by one-way ANOVA (Minitab 17, State College, PA, USA). The data on $\%$ seed germination was analyzed after arcsine transformation of values to ensure homogeneity of variance.

\section{Results}

\section{Isolation and Characterization of Bacteria from} SMS

A total of 6 morphologically different bacterial isolates were obtained from the SMS of A. bisporus. On the basis of $16 \mathrm{~S}$ rRNA gene sequences, these bacterial isolates were identified as Staphylococcus epidermidis (Sh1), S. aureus (Sh2), S. epidermidis (Sh3), Bacillus albus (Sh4), Delftia lacustris (Sh6) and Comamonas aquatica (Sh7) (Table 1). The 16S rRNA gene sequences of these bacterial isolates were deposited in the GenBank database with the accession numbers MT002750, MT002751, MT002756, MT002776, MT002777 and MT002779.

\section{Antagonistic Activity of Bacterial Isolates}

The antagonistic abilities of these bacterial isolates were determined against $P$. aphanidermatum using an in vitro dual-culture assay. The results indicated that none of the bacterial isolates showed considerable level of inhibition of mycelial growth of P. aphanidermatum. All the bacterial isolates recorded less than $5 \mathrm{~mm}$ inhibition zone (Table 2). Of the 6 bacterial isolates evaluated, S. epidermidis Sh3 produced the maximum inhibition zone of 4.2 $\mathrm{mm}$.

\section{Plant Growth Promoting Activity of Bacterial Isolates}

The bacterial isolates were tested for plant growth promotion effects on cucumber using a roll paper towel 
Table 2. Inhibition of mycelial growth of Pythium aphanidermatum by bacterial isolates from spent mushroom substrate of Agaricus bisporus

\begin{tabular}{|cc|}
\hline Bacterial Isolate & Inhibition zone $(\mathrm{mm})$ \\
\hline Staphylococcus epidermidis Sh1 & $3.0 \pm 0.8^{\mathrm{abc}}$ \\
Staphylococcus aureus Sh2 & $4.0 \pm 0.8^{\mathrm{ab}}$ \\
\hline Staphylococcus epidermidis Sh3 & $4.2 \pm 0.5^{\mathrm{a}}$ \\
\hline Bacillus albus Sh4 & $2.0 \pm 0.8^{\mathrm{c}}$ \\
Delftia lacustris Sh6 & $3.0 \pm 0.0^{\mathrm{abc}}$ \\
\hline Comamonas aquatica Sh7 & $2.5 \pm 0.6^{\mathrm{c}}$ \\
\hline
\end{tabular}

Data are mean of four replications \pm standard deviation. Values in the column with the same letter are not significantly different from each other at $\mathrm{P}<0.05$

technique. The results revealed that seed bacterization with C. aquatica Sh7, B. albus Sh4, D. lacustris Sh6 and S. epidermidis Sh3 resulted in a significant $(F=9.57, d f=6$, $\mathrm{p}<0.05$ ) increase in seedling vigour compared to control (Table 3). Among the various treatments, seeds treated with C. aquatica Sh7 showed the highest seedling vigor (Figure 1). No significant $(p<0.05)$ difference in the $\%$ seed germination among the treatments was observed.

\section{IAA Production}

All the 6 isolates of bacteria tested produced IAA between $0.28 \pm 0.02$ and $9.25 \pm 0.02 \mathrm{mg} \mathrm{L}^{-1}$ in tryptophan-amended growth medium (Table 4; Figure 2). The maximum (9.25 $\left.\mathrm{mg} \mathrm{L}^{-1}\right)$ and minimum $\left(0.28 \mathrm{mg} \mathrm{L}^{-1}\right)$ production of IAA was recorded with $C$. aquatica Sh7 and S. epidermidis Sh1, respectively.

\section{Discussion}

The existence of a broad range of bacterial species in the SMS has been documented (Ntougias et al., 2004; Watabe et al., 2004). Ntougias et al. (2004) reported the presence of bacterial genera Arthrobacter, Brevibacte- rium, Bacillus, Comamonas, Carnobacterium, Desemzia, Microbacterium, Paenibacillus, Exiguobacterium, Sphingobacterium and Staphylococcus in the spent mushroom compost of Agaricus spp. By using DNA sequence typing, several bacterial species including, Bacillus subtilis, Bacillus licheniformis, Paenibacillus lentimorbus, Pseudomonas mevalonii, Stenotrophomonas sp., Klebsiella/Enterobacter sp., Microbacterium sp. and Sphingobacterium multivorum have been reported in the spent mushroom compost (Watabe et al., 2004). The type of substrates used in the compost preparation and their pasteurization conditions are known to influence the diversity of bacterial communities in SMS (Ntougias et al., 2004). Choudhary (2011) isolated Acinetobacter sp., Pseudomonas sp. and Sphingobacterium sp. from the casing material for Agaricus bisporus. Zhu et al. (2014) found Comamonas serinivorans sp. nov. in wheat straw compost. Silva et al. (2009) reported the presence of Bacillus, Paenibacillus spp. and Streptomyces in a sugarcane bagasse and Cynodon dactylon straw compost used for A. brasilienses cultivation. Gbolagade (2006) reported the presence of Pseudomonas aeruginosa, Enterobacter aerogenes, Micrococcus roseus, Bacillus subtilis, B. cereus, B. polymyxa, B. licheniformis, Escherichia coli, Clostridium perfringens and Citrobacter freundii in the compost used for cultivation of Lentinus squarrosulus and Pleurotus tuber-regium. In the present study, Staphylococcus epidermidis (Sh1 and Sh3), S. aureus (Sh2), Bacillus albus (Sh4), Delftia lacustris (Sh6) and Comamonas aquatica (Sh7) were detected in the SMS of A. bisporus. The primary source of these bacteria might be the casing material or compost or water used for cultivation of mushrooms (Rainey et al., 1990; Choudhary, 2011; Kertesz and Thai, 2018; Cao et al., 2019).

Several bacteria isolated from compost are reported to have ability to suppress the growth of plant pathogenic fungi (Boulter et al., 2002; Suarez-Estrella et al., 2007; Sreevidya and Gopalakrishnan, 2017) and to promote plant growth (Chin et al., 2017; Sreevidya and Go-

Table 3. Effect of bacterial isolates from spent mushroom substrate of Agaricus bisporus on cucumber seed germination and seedling vigor

\begin{tabular}{lcccc}
\hline Bacterial Isolate & \% germination* & $\begin{array}{c}\text { Shoot length } \\
(\mathrm{cm})\end{array}$ & $\begin{array}{c}\text { Root length } \\
(\mathrm{cm})\end{array}$ & Vigour Index** \\
\hline Staphylococcus epidermidis Sh1 & $75.0 \pm 5.8$ & $6.3 \pm 1.5^{\mathrm{b}}$ & $14.8 \pm 3.8^{\mathrm{ab}}$ & $1583 \pm 293^{\mathrm{bc}}$ \\
$\quad$ Staphylococcus aureus Sh2 & $72.5 \pm 5.0$ & $6.1 \pm 1.5^{\mathrm{b}}$ & $16.1 \pm 2.1^{\mathrm{a}}$ & $1612 \pm 156^{\mathrm{bc}}$ \\
Staphylococcus epidermidis Sh3 & $75.0 \pm 5.8$ & $7.0 \pm 1.8^{\mathrm{b}}$ & $15.3 \pm 1.9^{\mathrm{ab}}$ & $1671 \pm 185^{\mathrm{b}}$ \\
Bacillus albus Sh4 & $75.0 \pm 5.8$ & $8.0 \pm 1.2^{\mathrm{ab}}$ & $16.6 \pm 3.2^{\mathrm{a}}$ & $1844 \pm 294^{\mathrm{ab}}$ \\
Delftia lacustris Sh6 & $75.0 \pm 5.8$ & $8.0 \pm 0.9^{\mathrm{ab}}$ & $16.1 \pm 1.9^{\mathrm{a}}$ & $1805 \pm 152^{\mathrm{ab}}$ \\
Comamonas aquatica Sh7 & $77.5 \pm 5.0$ & $9.1 \pm 1.6^{\mathrm{a}}$ & $17.0 \pm 2.5^{\mathrm{a}}$ & $2018 \pm 255^{\mathrm{a}}$ \\
Control & $72.5 \pm 5.0$ & $6.4 \pm 1.5^{\mathrm{b}}$ & $12.1 \pm 2.0^{\mathrm{b}}$ & $1343 \pm 160^{\mathrm{c}}$ \\
& ${ }^{*}$ Non-significant (P<0.05) ${ }^{* *}$ Vigor index was calculated by multiplying the \% germination of seeds with the sum of shoot length \\
and root length. Data are mean of three replications \pm standard deviation. Values in the column with the same letter are not \\
significantly different from each other at P<0.05
\end{tabular}


Table 4. Production of IAA by bacterial isolates from spent mushroom substrate of Agaricus bisporus

\begin{tabular}{cc} 
Bacterial Isolate & IAA $\left(\mathrm{mg} \mathrm{L}^{-1}\right)$ \\
\hline Staphylococcus epidermidis Sh1 & $0.28 \pm 0.02^{\mathrm{e}}$ \\
Staphylococcus aureus Sh2 & $1.07 \pm 0.01^{\mathrm{C}}$ \\
Staphylococcus epidermidis Sh3 & $0.77 \pm 0.01^{\mathrm{d}}$ \\
Bacillus albus Sh4 & $0.33 \pm 0.00^{\mathrm{e}}$ \\
Delftia lacustris Sh6 & $7.57 \pm 0.07^{\mathrm{b}}$ \\
Comamonas aquatica Sh7 & $9.25 \pm 0.02^{\mathrm{a}}$
\end{tabular}

Data are mean of four replications \pm standard deviation Values in the column with the same letter are not significantly different from each other at $\mathrm{P}<0.05$

palakrishnan, 2017). Riahi et al. (2012) identified three bacterial species viz, Bacillus subtilis, B. licheniformis and B. amyloliquefaciens from the extract of leached spent mushroom compost that showed antagonistic effect towards Lecanicillium fungicola, the causal agent of dry bubble disease of button mushroom. In the present study, none of the bacterial isolates showed substantial level of suppression of growth of P. aphanidermatum and all the bacterial isolates recorded less than $5 \mathrm{~mm}$ inhibition zone. However, plant growth promoting effect of these bacterial isolates was observed. Although no significant difference in \% seed germination was observed, seed bacterization with C. aquatica Sh7, B. albus Sh4, D. lacustris Sh6 and S. epidermidis Sh3 resulted in a significant increase in seedling vigor of cucumber compared to control and C. aquatica Sh7 treated seeds showed the maximum seedling vigour. Several reports indicate the beneficial effects of bacteria present in the substrates used for cultivation of mushrooms (Rainey et al., 1990; Straatsma et al., 1994; Ahlawat and Vijay, 2010). The bacteria such as Alcaligenes faecalis and Pseudomonas putida which are surviving in casing layer are reported to influence the growth and morphogenesis of A. bisporus by producing growth inducing compounds, which stimulate initiation of pinheads (Rainey et al., 1990). Straatsma et al. (1994) demonstrated that the thermophilic fungi present in mushroom compost enhanced the growth rate of Agaricus mycelium up to two fold. Inoculation with Bacillus megaterium or Staphylococcus has been shown to enhance mushroom production and early cropping (Ahlawat and Vijay, 2010). The increase in seedling vigor of cucumber in the present study could be as a result of production and release of growth promoting compounds like IAA by the bacterial isolates.

IAA is a common auxin and is a product of L-tryptophan metabolism of microorganisms. In bacteria, IAA is primarily synthesized via the indole-3-pyruvic acid pathway (Gomes et al., 2017). IAA produced by plant growth-promoting rhizobacteria (PGPR) is known to enhance root growth (Persello-Cartieaux et al., 2003) and the growth of root hairs (Desbrosses et al., 2009).
Asghar et al. (2002) observed a significant relationship between in vitro auxin production by PGPR and yield of Brassica juncea. Deepa et al. (2010) demonstrated that Enterobacter cloacae and Enterobacter aerogens strains, which produced IAA, exhibited growth-promoting effect in Vigna unguiculata. In addition to the effects of IAA produced by beneficial bacteria on plants, the growth and yield of mushrooms also reported to be influenced by IAA (Maniruzzaman et al., 2008; Ramachela and Sihlangu, 2016). Maniruzzaman et al. (2008) demonstrated that the culture media amended with IAA (5 ppm) caused rapid proliferation of oyster mushroom mycelia. Ramachela and Sihlangu (2016) reported that auxins promoted the cap size of Pleurotus ostreatus. In the present study, all the 6 bacterial isolates produced IAA in vitro and the production levels varied between 0.28 and $9.25 \mathrm{mg} \mathrm{L}^{-1}$. Among the bacterial isolates tested, C. aquatica Sh7 showed the highest production of IAA (9.25 $\left.\mathrm{mg} \mathrm{L}^{-1}\right)$. The same bacterial isolate displayed the highest plant growth promoting activity. These results suggest that IAA produced by this bacterial isolate might have involved in enhancing vigor of cucumber seedlings. An interesting observation in our study is that the bacterial isolate $B$. albus $B 4$, which is producing low amounts of IAA in vitro, enhanced the growth of cucumber. These results suggest that other mechanisms of action might have been involved in plant growth promotion by this bacterium. However, Schwachtje et al. (2012) reported that the non-growth promoting bacterial strains Pseudomonas sp. WCS417r and G53 isolated from the rhizosphere of Arabidopsis showed the highest levels of IAA production.

\section{Conclusion}

This study demonstrated the existence of different bacteria in SMS of Agaricus bisporus in Oman. These bacterial isolates displayed low levels of antagonism against P. aphanidermatum and produced less than $5 \mathrm{~mm}$ inhibition zone. However, these bacterial isolates enhanced the plant growth as demonstrated by increased seedling vigor of cucumber compared to control. The level of production of IAA by these bacterial isolates varied among isolates. Among the bacterial isolates tested, Comamonas aquatica Sh7 showed the highest production of IAA as well as plant growth promoting activity. Further studies are required to evaluate the potential of these bacterial isolates or their cell free culture filtrates in promoting growth of edible mushrooms and in enhancing plant growth under in vivo conditions.

\section{Acknowledgements}

This work was supported by the SQU research grants IG/AGR/ CROP/18/01 and RC/RG-AGR/CROP/19/02. We thank the Central Analytical and Applied Research Unit, SQU for HPLC analysis. 


\section{References}

Ahlawat OP, Vijay B. (2010). Potential of thermophilic bacteria as microbial inoculant for commercial scale white button mushroom (Agaricus bisporus) compost production. Journal of Scientific and Industrial Research. 69: 948-955.

Ahlawat OP, Manikandan K, Sagar MP, Raj D, Gupta P, Vijay B. (2011). Effect of composted button mushroom spent substrate on yield, quality and disease incidence of Pea (Pisum sativum). Mushroom Research 20: 87-94.

Al-Hussini HS, Al-Rawahi AY, Al-Marhoon AA, Al-Abri SA, Al-Mahmooli IH, Al- Sadi AM, Velazhahan R. (2019). Biological control of damping-off of tomato caused by Pythium aphanidermatum by using native antagonistic rhizobacteria isolated from Omani soil. Journal of Plant Pathology 101: 315-322.

Al-Shibli H, Dobretsov S, Al-Nabhani A, Maharachchikumbura SSN, Rethinasamy V, Al-Sadi AM. (2019). Aspergillus terreus obtained from mangrove exhibits antagonistic activities against Pythium aphanidermatum-induced damping-off of cucumber. PeerJ 7: 1-16 (Article e7884).

Albertsen $M$, Karst SM, Ziegler AS, Kirkegaard $\mathrm{RH}$, Nielsen PH. (2015). Back to basics- The influence of DNA extraction and primer choice on phylogenetic analysis of activated sludge communities. PLOS ONE. 10: 1-15 (Article e0132783).

Asghar H, Zahir Z, Arshad M, Khaliq A. (2002). Relationship between in vitro production of auxins by rhizobacteria and their growth-promoting activities in Brassica juncea L. Biology and Fertility of Soils 35: 231-237.

Boulter Jl, Trevors JT, Boland GJ. (2002). Microbial studies of compost: bacterial identification, and their potential for turf-grass pathogen suppression. World Journal of Microbiology and Biotechnology 18: 661671.

Cao G, Song $T$, Shen $Y$, Jin Q, Feng W, Fan L, Cai W. (2019). Diversity of bacterial and fungal communities in wheat straw compost for Agaricus bisporus cultivation. HortScience 54: 100-109.

Chin CFS, Furuya $Y$, Zainudin MHM, Ramli N, Hassan MA, Tashiro Y, Sakai K. (2017). Novel multifunctional plant growth-promoting bacteria in co-compost of palm oil industry waste. Journal of Bioscience and Bioengineering 124: 506-513.

Choudhary DK. (2011). First preliminary report on isolation and characterization of novel Acinetobacter spp. in casing soil used for cultivation of button mushroom, Agaricus bisporus (Lange) Imbach. International Journal of Microbiology 2011: 1-6 (Article 790285).
Deepa CK, Dastager SG, Pandey A. (2010). Isolation and characterization of plant growth promoting bacteria from non-rhizospheric soil and their effect on cowpea (Vigna unguiculata (L.) Walp.) seedling growth. World Journal of Microbiology and Biotechnology 26:1233-1240.

Desbrosses G, Contesto C, Varoquaux F, Galland M, Touraine B. (2009). PGPR-Arabidopsis interactions is a useful system to study signaling pathways involved in plant developmental control. Plant Signaling \& Behavior 4: 319-321.

Feeney MJ, Miller AM, Roupas P. (2014). Mushrooms-biologically distinct and nutritionally unique: exploring a "third food kingdom". Nutrition Today 49: 301-307.

Gbolagade JS. (2006). Bacteria associated with compost used for cultivation of Nigerian edible mushrooms Pleurotus tuber-regium (Fr.) Singer, and Lentinus squarrosulus (Berk.). African Journal of Biotechnology 5: 338-342.

Gomes IP, Matos ADM, Nietsche S, Xavier AA, Costa MR, Gomes WS, Cristian M, Pereira T. (2017). Auxin production by endophytic bacteria isolated from banana trees. Brazilian Archives of Biology and Technology 60: 1-13 (Article e17160484).

Goonani Z, Sharifi K, Riahi H. (2011). The effects of spent mushroom compost and municipal solid waste compost on Phytophthora drechsleri in vivo and in vitro. Archives of Phytopathology and Plant Protection 44: 1171-1181.

Hanafi FHM, Rezania S, Taib SM, Din MFM, Yamauchi M, Sakamoto M, Hara H, Park J, Ebrahimi SS. (2018). Environmentally sustainable applications of agrobased spent mushroom substrate (SMS): an overview. Journal of Material Cycles and Waste Management 20: 1383-1396.

Inagaki R, Yamaguchi A. (2009). Spent substrate of shiitake (Lentinula edodes) inhibits symptoms of anthracnose in cucumber. Mushroom Science and Biotechnology 17: 113-115.

Kang DS, Min KJ, Kwak AM, Lee SY, Kang HW. (2017). Defense response and suppression of Phytophthora blight disease of pepper by water extract from spent mushroom substrate of Lentinula edodes. Plant Pathology Journal 33: 264-275.

Kertesz MA, Thai M. (2018). Compost bacteria and fungi that influence growth and development of Agaricus bisporus and other commercial mushrooms. Applied Microbiology and Biotechnology 102: 1639-1650.

Kwak AM, Kang DS, Lee SY, Kang HW. (2015). Effect of spent mushroom substrates on Phytophthora blight disease and growth promotion of pepper. Journal of Mushroom 13: 16-20.

Maniruzzaman M, Haque AU, Nasiruddin KM. (2008). Effect of growth hormone on the mycelial growth and 
spawn production in Oyster mushroom. Bangladesh Journal of Agricultural Research 33: 51-58.

Ntougias S, Zervakis Gl, Kavroulakis N, Ehaliotis C, Papadopoulou KK. (2004). Bacterial diversity in spent mushroom compost assessed by amplified rDNA restriction analysis and sequencing of cultivated isolates. Systematic and Applied Microbiology 27: 746754.

Parada RY, Murakami S, Shimomura N, Otani H. (2012). Suppression of fungal and bacterial diseases of cucumber plants by using the spent mushroom substrate of Lyophyllum decastes and Pleurotus eryngii. Journal of Phytopathology 160: 390-396.

Parada RY, Murakami S, Shimomura N, Egusa M, Otani H. (2011). Autoclaved spent substrate of hatakeshimeji mushroom (Lyophyllum decastes Sing) and its water extract protect cucumber from anthracnose. Crop Protection 30: 443-450.

Patten CL, Glick BR. (1996). Bacterial biosynthesis of indole-3-acetic acid. Canadian Journal of Microbiology 42: 207-220.

Persello-Cartieaux F, Nussaume L, Robaglia C. (2003). Tales from the underground: molecular plant-rhizobacteria interactions. Plant, Cell \& Environment 26: 189-199.

Rainey PB, Cole ALJ, Fermor TR, Wood DA. (1990). A model system for examining involvement of bacteria in basidiome initiation of Agaricus bisporus. Mycological Research 94: 191-195.

Ramachela K, Sihlangu SM. (2016). Effects of various hormonal treated plant substrates on development and yield of Pleurotus ostreatus. Cogent Food \& Agriculture 2: 1-4 (Article 1276510).

Riahi H, Hashemi M, Sharifi K. (2012). The effect of spent mushroom compost on Lecanicillium fungicola in vivo and in vitro. Archives of Phytopathology and Plant Protection 45: 2120-2131.

Roy S, Barman S, Chakraborty U, Chakraborty B. (2015). Evaluation of spent mushroom substrate as biofertilizer for growth improvement of Capsicum annuum L. Journal of Applied Biology and Biotechnology 3: 022-027.

Schwachtje J, Karojet S, Kunz S, Brouwer S, van Dongen JT. (2012). Plant-growth promoting effect of newly isolated rhizobacteria varies between two Arabidopsis ecotypes. Plant Signaling \& Behavior 7: 623-627.
Shifa H, Gopalakrishnan C, Velazhahan R. (2015). Efficacy of Bacillus subtilis $\mathrm{G} 1$ in suppression of stem rot caused by Sclerotium rolfsii and growth promotion of groundnut. International Journal of Agriculture Environment and Biotechnology 8: 91-98.

Silva CF, Azevedo RS, Braga C, Silva RD, Dias ES, Schwan RF. (2009). Microbial diversity in a bagasse-based compost prepared for the production of Agaricus brasiliensis. Brazilian Journal of Microbiology 40: 590-600.

Sreevidya M, Gopalakrishnan S. (2017). Direct and indirect plant growth-promoting abilities of Bacillus species on chickpea, isolated from compost and rhizosphere soils. Organic Agriculture 7: 31-40.

Straatsma G, Olijnsma TW, Gerrits JPG, Amsing JGM, Op den Camp HJM, Van Griensven LJLD. (1994). Inoculation of Scytalidium thermophilum in button mushroom compost and its effect on yield. Applied and Environmental Microbiology 60: 3049-3054

Suarez-Estrella F, Vargas-Garcia C, Lopeza MJ, Capelb C, Morenoa J. (2007). Antagonistic activity of bacteria and fungi from horticultural compost against Fusarium oxysporum f. sp. melonis. Crop Protection 26: 46-53.

Szkop M, Bielawski W. (2013). A simple method for simultaneous RP-HPLC determination of indolic compounds related to bacterial biosynthesis of indole-3-acetic acid. Antonie Van Leeuwenhoek 103: 683-691.

Uzun I. (2004). Use of spent mushroom compost in sustainable fruit production. Journal of Fruit and Ornamental Plant Research 12: 157-165.

Watabe M, Rao JR, Xu J, Millar BC, Ward RF, Moore JE. (2004). Identification of novel eubacteria from spent mushroom compost (SMC) waste by DNA sequence typing: ecological considerations of disposal on agricultural land. Waste Management 24: 81-86.

Yohalem D, Nordheim E, Andrews J. (1996). The effect of water extracts of spent mushroom compost on apple scab in the field. Phytopathology 86: 914-922.

Zhu D, Xie C, Huang Y, Sun J, Zhang, W. (2014). Description of Comamonas serinivorans sp. nov., isolated from wheat straw compost. International Journal of Systematic and Evolutionary Microbiology 64: 4141-4146. 